\title{
Investigating the Effectiveness of Branding on Customer Loyalty in Some Selected Hotels in Accra, Ghana
}

\author{
Irene Seh Tah (Corresponding author) \\ Department of Hospitality Management \\ Takoradi Technical University, P. O. Box 256 \\ Takoradi, Ghana \\ Tel: 233-244-216-274Ｅ-mail: ireseh@ @otmail.com \\ Awo Kyemenua Darko \\ Ghana Institute of Management and Public Administration \\ P. O. Box AH50, Achimota \\ Accra, Ghana \\ Tel: 233-202-723-936_E-mail: awodarko@gmail.com
}

Received: August 30, 2018 Accepted: October 25, 2018 Published: December 17, 2018

doi:10.5296/gjes.v4i2.13576 URL: https://doi.org/10.5296/gjes.v4i2.13576

\begin{abstract}
The study investigated the effectiveness of branding on customer loyalty in some selected hotels in Accra. In all, 250 questionnaires were administered to the customers and 200 representing 80\% were retrieved. Five selected hotels in Accra were used for the research. The study revealed that some hotels apply branding strategies in selling their products while others do not. This was attributed to the fact that managers of those hotels are unaware of the benefits of effective branding strategies. The study also revealed that services that attract customers most to a hotel include front office, food and beverage and housekeeping. From management perspective, it was realized that $40 \%$ of customers mostly patronize housekeeping services and $40 \%$ also patronize food and beverage services mostly. Finally the study found that, factors such as trust, commitment, high quality services, customer satisfaction and reward programmes influence customer loyalty in the hotel industry. Customer satisfaction appeared
\end{abstract}




\section{Macrothink

to be the major factor that influences customer loyalty in hotels. Hotel managers and employees should therefore maintain a friendly relationship with customers and customer's needs should constantly be met as this could help to make customers highly satisfied.

Keywords: Branding, Loyalty, Hotel industry, Customers, Accra-Ghana 


\section{Introduction}

The hotel industry consists of a wide range of fields within the service sector that provides various hospitality facilities including accommodation, food and beverage, business meetings and events, leisure amenities, entertainment and recreation and tourism services. Being one of the dominating sectors in the service industry, hotel and hospitality services play a big role in contributing to the economy of a country (Joyw, 2010). In recent years, one of the most important factors affecting the hotel industries along with the entire service sector is considered to be branding.

Branding is a trademark or distinctive name identifying a product or a manufacturer. A key challenge to brand managers is how to gain a better understanding of the relationship between brand and customer loyalty constructs. Researchers have recognized that brand identity plays a key role in brand management (Shiraz, Lorestani, \& Mazidi, 2013). A successful branding strategy provides the hotel organization with great opportunities to achieve high managerial and financial performance and create a strong customer relationship, which are essential aspects for the survival in the industry. Branding introduces stability into a business and allows customers to shop with confidence in an increasing world (Ahmed \& Riwan, 2014). Brands are natural barriers to new competitors because branding reduces customer risk of purchasing particular services or product thus influencing customer to be loyal to a particular brand or brand image. To lead the domestic market and be a part of the global market, the hotel groups take initiatives to create and maintain customer relationship through building a unique and strong brand image (Adams, 2005). It is the fundamental objective of every organization to build on a good brand and strive at maintaining it. Branding is very important in every hotel industry since upon good branding the establishment can get loyal customers. Before a hotel can get a good brand it depends mostly on its facilities and services it provides (Reichheld, 2013).

Customer loyalty is one of the most important keys to the hotel success. Customer loyalty is where a person buys or uses a product from the same manufacturers repeatedly rather than from other suppliers (Reichheld, 2013). The Ghana Tourist Board (2013) reported that many hotels derive a large portion of their profits from their loyal customers. Customer loyalty leads to higher customer retention rate and to continuous business success even in situations where failure to satisfy customers would normally cause an early termination of business. Therefore the hotel operations must focus not only on attracting first-time customers but also on developing long-term relationship with customers (Adams, 2005). Loyalty is the demonstration which some customers show to a particular brand or brand image and the willingness to continue patronizing the brands services over a long time and recommending it to friends and associates (Lovelock \& Wirtz, 2010).

In the hotel industry branding is very important and should be taken very seriously since among the benefits from branding, customers are very much interested in hotels that provide good services and good customer relationship. Some hotels already have a brand name attached to them and they are known for their good services and facilities. Such hotels do not have much problem with customers, since customers know what they provide and are loyal to 
them (Hulten, 2011).

In today's society, branding is very important to every business and loyal customers are more likely to advoctate for the brabx and recommend it to relatives, friends and other potential consumers. However, Asiedu (2013) states that, nowadays hotels in Ghana are concerned that today's consumers tend to be less loyal. The glory of branding appears to be declining in particular to some of the one star hotels. He says that, there is more growing acceptance of the international labels brand and some three star hotels as in the present environment of increased competition and rapid market entry of new product and services into the marketplace, leads customers to experience better services and have a wider choice of better alternatives and opportunities.

Alternatively, the researchers have also observed that, looking at the trends in the Ghanaian hotel industry, although the hotels already existing in Ghana, especially the Ghanaian owned ones are expanding, they are not putting a lot of emphasis on branding. Customers are hard to attract and difficult to retain as is not very easy relatively in getting loyal customers due to the increasing number of hotels springing up in Ghana and most of these hotels have a similar standard in terms of product quality, price, performance, service etc and have no strategies put in place to maintain their loyal customers. However, the rational for embarking on the research is to critically investigate the effectiveness of branding on customer loyalty of some selected hotels in Accra.

The purpose of the study was to investigate the effectiveness of branding on customer loyalty in some selected hotels in Accra. This study will help hotels to create and maintain a good brand name. Additionally it will enhance on the hotels' ability to build and maintain loyal customers and allow customers to choose good branded hotels and good hotels with good facilities and services. Finally, this study will help to enhance the value of the hotel industry in that it would have offered good branding and encourage good customer loyalty on which depend much potential good in the progress of the nation's economy. This study seeks to: (1) find out the extent to which hotels apply branding as a business tool; (2) determine the services that attract customers to a particular hotel; (3) analyze the factors affecting customer loyalty and (4) investigate how brand image affects a customer decision to return to the same hotel.

\section{Literature Review}

\subsection{Concepts of Branding}

There have been various definitions of a brand in previous works. A brand is a name, a term, a sign, symbol or design or an amalgam of these to make the products and services of one seller or producer, distinct from those of others (Kyei, 2017). This definition has, however, been criticized as being too focused on the visual attributes of a product, such as its symbol, as the things that differentiate one seller from another (Mehdzi, Modjgan, \& Masoud, 2013). A brand is again defined as the set of attributes that the consumer buys to provide satisfaction; these attributes being real or illusory; rational or emotional and tangible or intangible (Ahmed \& Rizwan 2014). This is the reason why brands such as Rolex stand out. They have built a 
brand around the promise of prestige and exclusivity, which is intangible attributes that provide satisfaction to customers.

Basically, a brand is said to be not just a name, symbol or any other feature that distinguishes one product or service from another, but rather both tangible and intangible benefits that are perceived to be of value by the customer, which help in establishing an emotional connection between the customer and the product or services. One thing that stands out from these definitions of what a brand is, is that, sellers of products and services use various features, both tangible and intangible to differentiate themselves and shape customer perception of values (Flynn, 2009).

\subsection{Customer Loyalty in the Hotel Industry}

Customer loyalty, according to Yan (2015), is a deeply held commitment to rebuy or patronize a preferred product or service consistently in the future, thereby causing repetitive same brand or same brand-set purchasing, despite situational influences and marketing efforts having the potential to cause switching behaviour. The definition provided by Yan (2015) lays stress on the situational influences and marketing efforts which cause customers to switch over. A loyal customer is one who is not influenced by these factors and makes repeated purchases from the same seller or brand. Customer loyalty has been largely treated as either repurchase behaviour or repurchase behaviour combined with an attitudinal component. Consumer loyalty is considered an important key to organizational success and profitability.

Those consumers that demonstrate the greatest levels of loyalty toward the product or service activity tend to repurchase more often, and spend more money (Lach, 2000). As a result, a great deal of research attention has focused on the identification of effective methods of actively enhancing loyalty, including loyalty programmes such as point reward schemes. In contrast to these reward schemes, several researchers have argued that "customer loyalty can be increased by encouraging consumers to complain (Lach, 2000).

The concept of loyalty first appeared in the 1940s. Two separate loyalty concepts evolved. Namely, "brand preference" which was later referred to as attitudinal loyalty and "share of market" which was later referred to as behavioural loyalty. Nearly thirty (30) years after loyalty first appeared in the academic literature, researchers proposed that loyalty may be more complex and that it may comprise both attitudinal and behavioural loyalty. This bi-dimensional concept has since been combined and referred to as composite loyalty. The composite definition of loyalty has become the basis for much loyalty research that has since been undertaken. The composite definition of loyalty considers that loyalty should always comprise favourable attitudes; intentions and repeat-purchase. The combinational method involving both attitudes and behaviour is the most robust and appropriate as it captures the two major influences of consumer decision making (Bennett, 2001).

\section{Methods}

The study adopted a descripto-explanatory research; a combination of both descriptive and explanatory research design (Twenefour, 2017). The design allowed detailed description and analysis of the variables under study; describing and presenting their attributes and explaining 


\section{Macrothink}

Global Journal of Educational Studies

ISSN 2377-3936

2018, Vol. 4, No. 2

their relationships without manipulations (Twenefour et al., 2015). The study covered 200 respondents (customers) and 10 management from selected hotels in Accra, Ghana. A semi-structured, self-administered questionnaire was used to collect data. Before administration, the questionnaire was pilot-tested and subjected to reliability test using Cronbach Alpha; resulting in a reliability coefficient of 0.949 which was above the recommended minimum of 0.7 (Santos \& Reynolds, 1999; Twenefour, 2017). Data collected was analyzed using the statistical package for service solution (SPSS version 21). Descriptive statistics was used to explain the variable characteristics (Twenefour et al., 2015).

\section{Results and Findings}

Table 1 represents the demographic data of 200 customers (respondents) who participated in the study. From the table it can be observed that out of 200 respondents, 94 respondents representing $47.0 \%$ were males while the remaining 106 respondents representing $53.0 \%$ were females. Of the ten managers interviewed, six were males while four were females.

Table 1. Demographic characteristics of respondents

\begin{tabular}{|l|l|c|c|}
\hline \multicolumn{1}{|c|}{ Responses } & Characteristics & Frequency & Percentage $\{$ \% \\
\hline \multirow{4}{*}{ Gender } & Male & 94 & 47.0 \\
\cline { 2 - 4 } & Female & 106 & 53.0 \\
\cline { 2 - 4 } & TOTAL & $\mathbf{2 0 0}$ & $\mathbf{1 0 0 \%}$ \\
\hline \multirow{5}{*}{ Ege } & $20-30$ & 61 & 30.5 \\
\cline { 2 - 4 } & $31-40$ & 41 & 20.5 \\
\cline { 2 - 4 } & $41-50$ & 95 & 47.5 \\
\cline { 2 - 4 } & $51-60$ & 3 & 1.5 \\
\cline { 2 - 4 } & TOTAL & $\mathbf{2 0 0}$ & $\mathbf{1 0 0 \%}$ \\
\hline & Basic & 16 & 8.0 \\
\cline { 2 - 4 } & Secondary & 75 & 37.5 \\
\cline { 2 - 4 } & Degree/Diploma & 98 & 49.0 \\
\cline { 2 - 4 } & Postgraduate & 11 & 5.5 \\
\cline { 2 - 4 } & Others & $\mathbf{2 0 0}$ & $\mathbf{1 0 0 \%}$ \\
\cline { 2 - 4 } & TOTAL & & 0 \\
\hline
\end{tabular}

With regards to age, it was found that 61 customers representing $30.5 \%$ were between the ages of 20-30, 41 respondents representing 20.5\% were between 31-40 years, 79 respondents representing $47.5 \%$ were between $41-50$ years and 3 respondents representing $1.5 \%$ were between 51-60 years. As part of the demographics of the customers, table 1 also shows the academic or professional qualifications. Eleven of the respondents sampled, representing about $6 \%$ have post graduate education. Ninety eight respondents representing $49 \%$ have either a university or polytechnic background while 75 of the respondents representing about $38 \%$ have senior high school, vocational or technical educational background. The rest of the 
16 customers represent $8 \%$ have obtained basic educational qualification. As regards the managers who were interviewed, eight of them have had polytechnic, university or post-graduate experience

Table 2. The extent to which hotels apply branding as a business tool

\begin{tabular}{|c|c|c|}
\hline Responses & Frequency & Percentage \\
\hline Yes & 139 & 69.5 \\
No & 61 & 30.5 \\
Agree & 161 & 80.5 \\
Disagree & 39 & 19.5 \\
\hline
\end{tabular}

Table 2 out of the 200 customer respondents, 161 reacted to the question that asked whether or not customers have purchased from other hotels, out of this number, 139 (about 69.5\%) respondents indicated they have purchased from other hotels in the vicinity before whilst 39 (about 19.5) respondents said they have not. This means that majority of the respondents switched from other hotels and the minority have been loyal for a long time. In support of this, Hsieh, Pan, and Setiono (2004) affirmed that a successful brand enables consumers to identify the needs that the brand satisfies and to differentiate the brand from its competitors, and consequently increases the likelihood that consumers will purchase the brand. On the other hand, all managers indicated that there are other competitors in the area in which they operate. Where there is competition, hotels tend to deliver higher quality services to ensure that customers always choose them over other suppliers and when there is no competition, some hotels tend to operate the way they like due to monopoly power.

Table 3. Summary of services that attract customers to a hotel

\begin{tabular}{|l|c|c|}
\hline Services & Responses & Percentage $\{$ \% \\
\hline Food and beverage services & 76 & 38 \\
\hline Front office service & 33 & 16.5 \\
\hline Housekeeping services & 25 & 12.5 \\
\hline Business services & 19 & 9.5 \\
\hline Entertainment services & 30 & 15 \\
\hline After sale services & 17 & 8.5 \\
\hline TOTAL & $\mathbf{2 0 0}$ & $\mathbf{1 0 0}$ \\
\hline
\end{tabular}

From Table 3 all the respondents stated that the hotel offer Food and beverage services, Front office service, Room services and Housekeeping services. Nineteen of respondents representing $9.5 \%$ said the hotel offers business services attached to the other services, 30 respondents representing $15 \%$ said the hotels offer entertainment services and 17 respondents 
representing $8.5 \%$ also stated that the hotel offer after sale services. This result declares that most hotels do not follow up on customers after they leave the premises. This is a bad habit and a challenge facing most hotel operations in developing countries. In response to the type of products and services that the hotel offers, all the managers said hotels offer food and beverage services, housekeeping services, and entertainment services. On the other hand, 3 managers said the hotels offer front office service and after sale service. The table therefore revealed that all the hotels studied together offer all the products and services mentioned.

From Table 4, majority (186) of the respondents representing 93\% agreed that strong customer relationship can be built based on trust, while 14 respondents representing $7 \%$ opposed that strong customer relationship can be built based on trust. Gounaris (2003) argued that trust is a vital element in any type of relationship. The more a customer trusts a supplier, the higher is the perceived value of the relationship; consequently, the greater the chances that the customer remains in the relationship will be. From Table 4, majority (186) of the respondents representing $93 \%$ agreed that strong customer relationship can be built based on trust, while 14 respondents representing $7 \%$ opposed that strong customer relationship can be built based on trust. Gounaris (2003) argued that trust is a vital element in any type of relationship. The more a customer trusts a supplier, the higher is the perceived value of the relationship; consequently, the greater the chances that the customer remains in the relationship will be.

Table 4. Summary of factors affecting customer loyalty

\begin{tabular}{|l|c|c|c|}
\hline \multicolumn{1}{|c|}{ Factors } & Responses & Frequency & Percentage\{\%\} \\
\hline \multirow{2}{*}{$\begin{array}{l}\text { Strong customer relationship can be } \\
\text { built base on trust }\end{array}$} & Agree & 186 & 93 \\
\cline { 2 - 4 } & Disagree & 14 & 7 \\
\cline { 2 - 4 } & TOTAL & $\mathbf{2 0 0}$ & $\mathbf{1 0 0}$ \\
\hline $\begin{array}{l}\text { Customers buy more when they have } \\
\text { high commitment in the hotel's product } \\
\text { or services. }\end{array}$ & Agree & 156 & 78 \\
\cline { 2 - 4 } & Disagree & 44 & 22 \\
\hline \multirow{2}{*}{$\begin{array}{l}\text { High quality services influence } \\
\text { customers to be loyal to a particular } \\
\text { hotel. }\end{array}$} & TOTAL & $\mathbf{2 0 0}$ & $\mathbf{1 0 0}$ \\
\cline { 2 - 4 } & Disagree & 200 & 100 \\
\hline $\begin{array}{l}\text { Customers become loyal to a hotel } \\
\text { when they are highly satisfied by the }\end{array}$ & TOTAL & $\mathbf{2 0 0}$ & 0 \\
\cline { 2 - 4 } hotel's services and products. & Disagree & 200 & 100 \\
\cline { 2 - 4 } & TOTAL & $\mathbf{2 0 0}$ & $\mathbf{1 0 0}$ \\
\hline Rewarding customers for repeat \\
purchase increase customer satisfaction \\
and loyalty & Agree & 143 & 71.5 \\
\cline { 2 - 4 } & Disagree & 57 & 28.5 \\
\cline { 2 - 4 } & TOTAL & $\mathbf{2 0 0}$ & $\mathbf{1 0 0}$ \\
\hline
\end{tabular}

From the results, it can be seen that 156 respondents representing $78 \%$ affirmed that customers buy more when they have high commitment in the hotel's product or services 
while 44 respondents representing $22 \%$ disagreed to the statement. The result revealed that customers increase their purchases if they become highly committed due to the benefits they derive from the hotel's products and services. This agrees with Shiraz, Lorestani, and Mazidi, (2013) who affirmed that customers who have high commitment in a product or service will buy more. In other words, commitment leads to behavioural aspect of loyalty. In support of this notion, Ahmed and Rizwan (2014) found a significant path from resistance to change commitment to loyalty.

All respondents representing $100 \%$ asserted that high quality services influence customers to be loyal to a particular hotel. This signifies that if a hotel increases the quality of services provided to customers, customers' expectations will be met hence this may influence repurchase intention of customers. As said by Yan (2015), customers will have the strong intention to return and stay in the same hotel or resort they have stayed in before if the past service quality performed met their expectations. All the respondents (100\%) who participated in the survey affirmed that customers become loyal to a hotel when they are highly satisfied by its services and products. This result shows that customer satisfaction has a significant correlation with customer loyalty. According to Alhadad and Al-maslam (2016), the impact of satisfaction on loyalty has been the most popular subject. Several studies have revealed that there is a strong connection between satisfaction and loyalty. Satisfied customers become loyal and dissatisfied customers move to another vendor. The level of satisfaction is always high when the customer gives minimum price and gets maximum of usage and profit. Finally, from the table, 143 respondents representing $71.5 \%$ agreed that rewarding customers for repeat purchase increases customer satisfaction and loyalty.

Table 5. Summary of factors affecting customer loyalty

\begin{tabular}{|c|c|c|c|}
\hline Factors & Responses & Frequency & Percentage $\{\%\}$ \\
\hline \multirow{3}{*}{$\begin{array}{l}\text { Strong customer relationship can be } \\
\text { built base on trust }\end{array}$} & Agree & 41 & 91.1 \\
\hline & Disagree & 4 & 8.8 \\
\hline & TOTAL & 45 & 100 \\
\hline \multirow{3}{*}{$\begin{array}{l}\text { Customers buy more when they have } \\
\text { high commitment in the hotel's product } \\
\text { or services. }\end{array}$} & Agree & 34 & 75.5 \\
\hline & Disagree & 11 & 24.4 \\
\hline & TOTAL & 45 & 100 \\
\hline \multirow{3}{*}{$\begin{array}{l}\text { High quality services influence } \\
\text { customers to be loyal to a particular } \\
\text { hotel. }\end{array}$} & Agree & 45 & 100 \\
\hline & Disagree & 0 & 0 \\
\hline & TOTAL & 45 & 100 \\
\hline \multirow{3}{*}{$\begin{array}{l}\text { Customers become loyal to a hotel } \\
\text { when they are highly satisfied by the } \\
\text { hotel's services and products. }\end{array}$} & Agree & 45 & 100 \\
\hline & Disagree & 0 & 0 \\
\hline & TOTAL & 45 & 100 \\
\hline \multirow{3}{*}{$\begin{array}{l}\text { Rewarding customers for repeat } \\
\text { purchase increase customer satisfaction } \\
\text { and loyalty }\end{array}$} & Agree & 43 & 95.5 \\
\hline & Disagree & 2 & 4.4 \\
\hline & TOTAL & 45 & 100 \\
\hline
\end{tabular}


From Table 5, majority (41) of the respondents representing 91.1\% agreed that strong customer relationship can be built based on trust, while 4 respondents representing $8.8 \%$ opposed that strong customer relationship can be built based on trust. Gounaris (2003) argued that trust is a vital element in any type of relationship. The more a customer trusts a supplier, the higher is the perceived value of the relationship; consequently, the greater the chances that the customer remains in the relationship will be.

From the results on Table 5, it can be seen that 34 respondents representing $75.5 \%$ affirmed that customers buy more when they have high commitment in the hotel's product or services while 11 respondents representing $24.4 \%$ disagreed to the statement. The result revealed that customers increase their purchases if they become highly committed due to the benefits they derive from the hotel's products and services. This agrees with Bennet (2001) who affirmed that customers who have high commitment in a product or service will buy more. In other words, commitment leads to behavioural aspect of loyalty. In support of this notion Shiraz, Lorestani and Mazidi (2013) found a significant path from resistance to change commitment to loyalty. All respondents representing $100 \%$ asserted that high quality services influence customers to be loyal to a particular hotel. This signifies that if a hotel increases the quality of services provided to customers, customers' expectations will be met hence this may influence repurchase intention of customers. Hughes (2000) suggest that customers will have the strong intention to return and stay in the same hotel or resort they have stayed in before if the past service quality performed met their expectations.

Also, all the respondents (100\%) who participated in the survey affirmed that customers become loyal to a hotel when they are highly satisfied by the hotel's services and products. This result shows that customer satisfaction has a significant correlation with customer loyalty. According to Asiedu (2013), the impact of satisfaction on loyalty has been the most popular subject of studies. Several studies have revealed that there exists a direct connection between satisfaction and loyalty. Satisfied customers become loyal and dissatisfied customers move to another vendor. The level of satisfaction is always high when the customer gives minimum price and gets maximum of usage and profit.

Finally, 43 respondents representing $95.5 \%$ agreed that rewarding customers for repeat purchase increases customer satisfaction and loyalty. On the other hand, 2 respondents representing 4.4\% disagreed. Bolton, Kannan, and Bramlett (2000) argued that loyalty rewards programmes have become common in several service industries such as the hotel industry. The authors argue that generally, the aim of such programmes has been to increase customer loyalty in profitable segments by providing increased satisfaction and value to certain customers. One argument used by managers for these programmes is that increased satisfaction and loyalty leads to increased profitability (see Table 5).

\subsection{Findings}

From the study it was found that some of the hotels apply branding strategies in selling their products to customers. However some hotels do not. This is because the results revealed that majority of the respondents $(55.5 \%)$ said packaged products offered do not have the name and symbol of the hotel on it. This can be attributed to the fact that managers of those hotels 
are unaware of the benefits of adopting effective branding strategies in their operation. Based on objective two, the study found that services that attract customers most to a hotel includes front office services, food and beverage services and housekeeping services.

From management perspective, it was realized that $40 \%$ of customers mostly patronize housekeeping services and $40 \%$ also patronize food and beverage services. The study also disclosed that factors such as trust, commitment, high quality services, customer satisfaction and reward programmes influence customer loyalty in the hotel industry. For instance from the study $91.1 \%$ agreed that strong customer relationship can be built based on trust, $75.5 \%$ of respondents affirmed that customers buy more when they have high commitment in the hotel's product or services and $95.5 \%$ of respondents agreed that rewarding customers for repeat purchase increase customer satisfaction and loyalty.

Customer satisfaction appeared to be the major factor that influence customer loyalty as all the respondents (100\%) affirmed that customers become loyal to a hotel when they are highly satisfied by the hotel's services and products. Lastly, the study revealed that there exists a significant positive relationship between brand image and repurchase intention of customers. Therefore if management is able to improve the brand image of the business, this can foster customer retention and also increases the reputation of the company and vice versa.

\section{Conclusions and Recommendations}

In today's world where it is becoming increasingly difficult to distinguish one product from another, it is even more important to have the support of a powerful brand. Clear definitions of brand strategy are a basis for successful management. Knowing that the most neglected marketing opportunity in the Business-to-Business arena is the building of a strong brand leads to the necessity to have a clear basis for distinction. Different customer loyalty factors such as trust, commitment, high quality services, customer satisfaction and reward programme were discussed in the study. It is concluded that all the factors were important and were effective under the umbrella of brand image to influence customer loyalty. Branding strategies have a significant influence on customer loyalty. Branding strategies and factors affecting customer loyalty are mutually interdependent; hotels should therefore improve on their branding strategies so as to ensure customer satisfaction and loyalty.

Based on the findings obtained from the survey, some of the possible recommendations are outlined below; Management should pay attention to those factors that may help to induce customers to patronize very often. Management should improve on their branding strategies so as to build a strong brand and lure more loyal customers. This will in effect help to differentiate the hotel's products from those of competitors. Hotel managers should offer more improved products and services to the existing ones so as to maintain their existing customers and also attract new ones.

Management should also follow-up on customers after they leave the hotel premises and also recommend other new products the hotel currently has. This makes customers feel recognized and important and as such influence customers to revisit the premises. As a result, this can help to increase profit margin and attraction of new customers. People get to know a hotel 
better when its products have the name and symbol of the establishment on it. This can help customers to easily identify a particular hotel brand and the needs it satisfies. It therefore becomes very necessary for all hotels to have the name and symbol of the company on all packaged products. Other equipment and materials used in delivering services to customers such as crockery, serviette, towels, linens and others should also have these features on it.

Finally, quality of products and services offered to customers must be improved and developed in order to meet and exceed customers' expectations as this can lead to positive word-of-mouth and customer retention.

\section{References}

Adams, P. (2005). Measuring Brand Equity across Products and Markets. California Management Review, 38(3), 102-120.

Ahmed, Z., \& Rizwan, M. (2014). Effects of Brand Trust and Customer Satisfaction on. Iranian Journal of Management Studies, 6(2), 153-178.

Alhadad, A. A., \& Al-maslam, S. (2014). Effects of Brand Trust and Customer Satisfaction in Brand Loyalty in Bahalwpur. Journal of Sociological Research, 5(1).

Asiedu, A. B. (2013). Prospects for an Emerging Tourism Industry in Ghana. Research Review (NS), 13(1\&2), 14-15.

Bennett, R. (2001). A Study of Brand Loyalty in the Business-to-Business Services Sector (p. 258). University of Queensland, Brisbane: School of Management.

Flynn, J. (2009). Churches Communicating a Message of Hope, Global Zenit News. Educational Institute of the American Hotel \& Motel Association, Michigan.

Ghana Tourist Board (2013), Tourism Statistical Factsheet on Ghana. Retrieved from http://www.touringghana.com/Tourism_Statistical_FactSheet_070316.pdf

Gounaris, S. P. (2003). Trust and Commitment Influences on Customer Retention: Insights from Business-to-Business Services. Journal of Business Research, 126-140.

Hsieh, M. H., Pan, S. L., \& Setiono, R. (2004). Product, Corporate and Country-Image Dimensions and Purchase Behavior: A Multi-country Analysis. Journal of the Academy of Marketing Science, 32(3), 251-270. https://doi.org/10.1177/0092070304264262

Hughes, A. (2003). The Customer Loyalty Solution: What Works and What Doesn't in Customer Loyalty Programmes. McGraw- Hill, USA.

Hultén, B. (2011). Sensory Marketing: The Multi-Sensory Brand-Experience Concept. European Business Review, 23(3), 256-273. https://doi.org/10.1108/09555341111130245

Joyw, F. (2010). The Impact of Interpersonal Relationships on Customer Satisfaction and Loyalty to the Service Provider. International Journal of Service Industry Management, 15(4), 365-384.

Kyei, E. B. (2017). Assessing the Effects of Branding on Consumer Behaviour (thesis). 


\section{Macrothink}

Global Journal of Educational Studies

ISSN 2377-3936 2018, Vol. 4, No. 2

Kwame Nkrumah University of Science and Technology. Kumasi, Ghana

Lach, J. (2000). Redeeming Qualities. American Demographics, 22(5), 36-38.

Lovelock, C., \& Wirtz, J. (2010). Services Marketing: People, Technology and Strategy. Prentice Hall, New Jersey.

Mehdzi, S. J., Modjgan, K., \& Masoud, J. (2013). Investigating the Investigation of the Effective Factos on Brand Loyalty and Repurchase Intention. Research Journal of Recent Sciences, 2(2), 10-17.

Reichheld, F. (2013). Zero Defections: Quality Comes to Services. Harvard Business Review, 105-112.

Shiraz, A., Lorestani, H. Z., \& Mazidi, A. K. (2013). Investigating the Effects of Branding on Customer Loyalty from Social Indentity Pespertive. Iranian Journal of Management Studies, 6(2), 153-178.

Twenefour, F. B. K. (2017). The Influence of Family Background on Students' Academic Performance. Academic Journal of Educational Research, 5(8), 216-222.

Twenefour, F. B. K., Sekyi, E. \& Fynn, P. (2015). A Situational Analysis of Pregnancy Related Challenges in the Sekondi-Takoradi Metropolis, Ghana. Journal of Natural Science Research, 5(6).

Yan, Z. (2015) Factors Influencing Customer Loyalty in the Hotel Industry (thesis). University of Utara Malaysia.

\section{Copyright Disclaimer}

Copyright for this article is retained by the author(s), with first publication rights granted to the journal.

This is an open-access article distributed under the terms and conditions of the Creative Commons Attribution license (http://creativecommons.org/licenses/by/3.0/). 